\title{
VISUAL STUDIES: IDENTIFICATION OF CANGKUANG TEMPLE AS A HERITAGE RELIC OF ANCIENT SUNDA KINGDOM WITH JUXTAPOSING TECHNIQUE
}

\author{
Rahmadi, Aldi M Fitrah \\ Photography Study Program, Faculty of Arts and Literature \\ Setiabudhi 193 Bandung West Java Indonesia \\ rahma_sans@yahoo.co.id aldi.m.fitrah@gmail.com
}

Pasundan University

Bandung, West Java, Indonesia

\begin{abstract}
West Java is home to a number of relics of buildings and ancient artifacts that bear the traits of Hindu, Buddhist, and other earlier cultures' structures. The Cangkuang Temple (8M) in Garut, West Java, is one of these ruins. This temple, built in the Hindu style, is thought to be a vestige of the Ancient Sundanese Kingdom. What's notable about this Cangkuang Temple structure is that it differs significantly from other sacred Sundanese temples built around the same time and in the same area. This Cangkuang Temple has some architecture characteristics with Ancient Sundanese structures, but it also has a number of unique architectural aspects. This raises the question of whether Cangkuang Temple is a genuine relic of the Ancient Sundanese Kingdom or a relic of a different era. As a result, the writer attempts to address the subject of these traits and disparities in this research. The writer uses the Diptych and Triptych techniques to compare the temple photo and the comparator to determine the similarities and differences of the temples as objects. The research approach employed in this study is a descriptive qualitative visual study, comprising field observations, literature reviews, and interviews as data gathering methods. The religious buildings of the Sundanese people of the same era, as well as those in the surrounding area, are observed. Finally, after the photos have been juxtaposed, they will be validated again to arrive at a final conclusion. This study includes comparisons with Gedong Songo Temple, which adds to the existing comparisons of buildings from the Tarumanegara (Batujaya), Ancient Sundanese (Bojongmenje), and Galuh / Kalingga / Medang (Gedong Songo) eras.
\end{abstract}

Keywords: Visual Studies, Photography, Diptych, Triptych, Temple, Ancient Sundanese

\section{Introduction}

In West Java region before the entry of Islam, there were various relics of ancient construction and artifacts that have the characteristics of Hinduism,
Buddhism and older cultures of various kingdoms. One of them was in the form of a temple, which was built by silpin in collaboration with various parties, 
with the provision of the form of temple buildings, statues, and reliefs arranged in the Book of Vastusastra. One interesting relic is Cangkuang Temple which was built around the eighth century (8AD) (Munandar, 2017) which has similar feature with Hindu buildings patterns and located in Garut West Java. This temple is believed to be a relic of the Ancient Sunda Kingdom. Cangkuang temple is estimated to be the same age as the establishment of the Ancient Sunda Kingdom, which is around the eighth century ( $8 \mathrm{AD}$ ), and has the characteristics of Hindu construction patterns. But what is interesting is that this temple has quite different features with other Ancient Sundanese sacred buildings in the same era and also those in the surrounding area, such as Bojongmenje Temple, Batujaya Temple, Pananjung Temple, Ronggeng Temple, Rajegwesi Temple, Karangkamulyan Site, and Astana Gede Site. Whereas based on its history Cangkuang Temple is located in the region and in the glory of the Ancient Sunda Kingdom, namely from the 6th year $\mathrm{AD}$ to $14 \mathrm{AD}$ (Munandar, 2010). This what makes the status of Cangkuang Temple as a relic of the Ancient Sunda Kingdom is still debated.
This Ancient Sunda Kingdom is the successor of the Kingdom of Tarumanegara, together with Galuh Kingdom. But when the Ancient Sunda Kingdom stood, the heritage temple of the Tarumanegara Kingdom has many similarities with the heritage temples of the Ancient Sunda Kingdom and Galuh. While most relics from the Tarumanegara Kingdom have temples with simple architectural characteristics such as Batujaya Temple with Buddhist patterns (Munandar, 2010: 72), while for Cangkuang Temple itself is estimated to be at the time of the transition of Tarumanegara and the Ancient Sunda Kingdom. Relics from Ancient Sunda have differences from the same Galuh which equally the successor of Tarumanegara. Candi Cangkuang has some similarities with the characteristics of Ancient Sundanese buildings, although there are also quite different, it could be the original of this temple before the restoration more like a heritage building at the beginning of the establishment of Ancient Sunda with buildings and roofs that tend to be simple and andesite rock materials (Munandar, 2010: 91). Therefore, this study also included comparisons with Gedong Songo 
Temple, especially on the roof, to see if it has similarities, because the roof of Cangkuang Temple at the time of restoration is no longer there. Moreover Hindu temples in Central Java were chosen as a reference for the time of restoration. So the addition of Gedong Songo Temple will complement the existing comparison between Tarumanegara era buildings (Batujaya), Ancient Sundanese (Bojongmenje) and Galuh / Kalingga / Medang (Gedong Songo) to see the comparison of its characteristics.

Visual studies are usually used to understand and interpret images such as photographs, films, paintings and others to provide more detailed value and information on the object that being studied and also can provide and convey more information (Barbour, 2014). In this study, visual studies can provide a better understanding and interpretation of the comparison of temple characteristics with photographic media to provide more detailed information for the analysis process, and also because visual studies have free and general nature. One of the difficulties that exist in the process of analyzing relics of the Ancient Sunda Kingdom is due to the nature of the Ancient Sundanese building itself which uses many materials that are not durable, so that today many of the remaining relics are no longer complete in shape and difficult in mapping or determining the special characteristics of the actual Ancient Sundanese building in detail. In addition, the characteristics of ancient Sundanese temple buildings are not well documented in various literature because they are only limited to displaying their form. The characteristics of the temples are not visualized properly which make this analysis process more difficult. Therefore, the author tried to make an analysis of the characteristics of Candi Cangkuang through the medium of photography based on references that have been obtained with qualitative descriptive methodologies and visual study methods entitled "Identification of Cangkuang Temple as a Heritage Relic of the Ancient Sunda Kingdom". Visual studies are used in this study because it can increase the richness and strength of data from the object analyzed, because the use of visual studies can provide understanding, interpretation, and also provide more detailed information in qualitative research for the existing analysis process (Pain, 
2012). In addition, visual photography studies with this juxtaposing technique will also be used to confirm and validate data that has been collected by relevant experts to clarify the results of analysis about the possible origin of the temple.

\section{Research Methods}

Research uses qualitative descriptive methodologies of visual study methods, because this research seeks to describe all existing symptoms or circumstances, namely the state of symptoms as they were at the time of the study. Mukhtar (2013:28) and provide more detailed value and information on the object of the findings being studied and can also provide and convey more information. In this study, field observations were conducted in Garut for Cangkuang Temple as the main object temple, then in Karawang for Batujaya Karawang Temple and Rancaekek for Bojongmenje Temple as a comparison temple while at Gedong Songo Temple the author got data through literature review as part of the results of direct visits. The author will try to sort and map the characteristics of the temple building based on literature review to then conduct analysis and also interviews to validate the results then describe the results as documentation of photography.

\section{Data Collection and Identification}

The author begins by collecting literature review data, namely the history of Hinduism - Buddha, the characteristics and relics of the Ancient Sunda Kingdom, and the restoration to the history of Cangkuang Temple and collecting images related to the temple. Then the author made observations by visiting Batujaya Temple, Bojongmenje Temple, and Cangkuang Temple, as well as Gedong Songo Temple. After observations the author conducted an interview with the source to validate the findings. Once validated, the results are then made into photographic documentation with the technique of juxtaposing diptych and triptych. Gedong Songo Temple was included for comparison because of its distance so direct observation could not be made. Gedong Songo Temple has similar characteristics to Cangkuang Temple so it is thought to have a connection in its history such as, Rectangular shape, the size is not too large, about 4 to 5 meters 
high, standing on a stone, the temple legs are 1 meter high, the temple legs are decorated in the form of tendril sculptures and flower or padma sculptures around it. Standing facing east There is a small staircase at the entrance On the inside there is a narrow room. The outside looks plain without relief decorations, only simple floral sculptures such as an empty frame in the middle. Therefore, with the comparison of these characteristics are expected to be more clarifying about the characteristics and buildings of the Cangkuang Temple that are compared.

\section{Diptych Juxtaposition Photo techniques}

In this process the author analyzes the photos obtained and also the images derived from references. The author performs a comparison with a photograph or a picture. With the help of an image processing application each photo or temple image is similar or has similarities with the temple juxtaposed next to each other. And the purpose of using Diptych is to be more specific and detailed on what it compares to while the use of Triptych so that the photos compared have a wider or more holistic viewing angle.

\section{A. The Temple Leg}

Here is a comparison of each temple leg. Batujaya Temple uses red brick and Bojongmenje Temple and Cangkuang Temple uses andesite rocks.

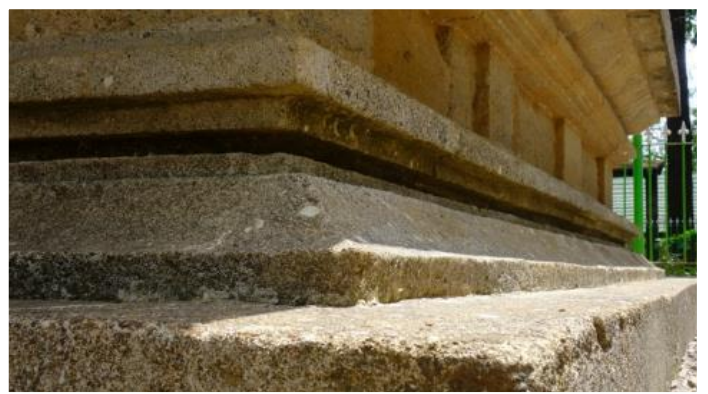

The legs in Cangkuang Temple have no relief.

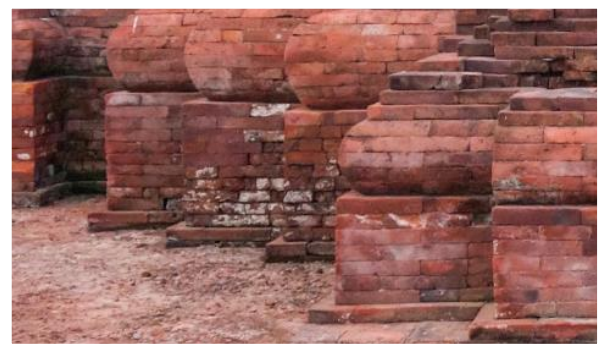

On the leg of Batujaya temple was not found relief. 


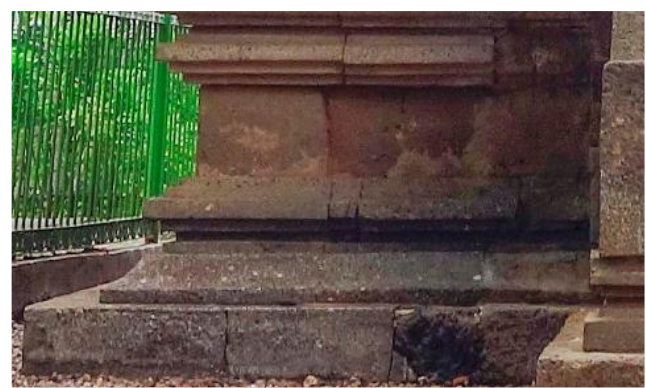

The construction of Cangkuang Temple uses bright ash andesite stone material and around the temple there are no reliefs.

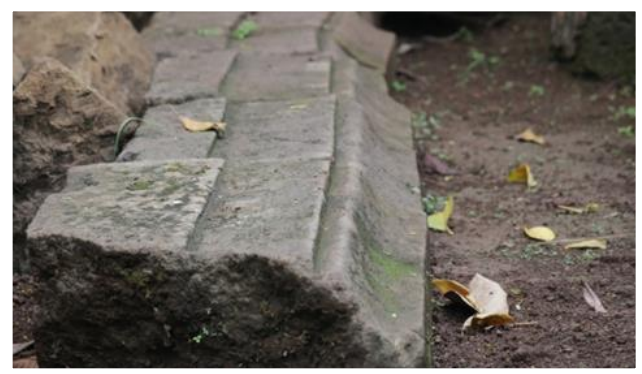

Bojong Temple uses the same andesite stone material as Cangkuang Temple.

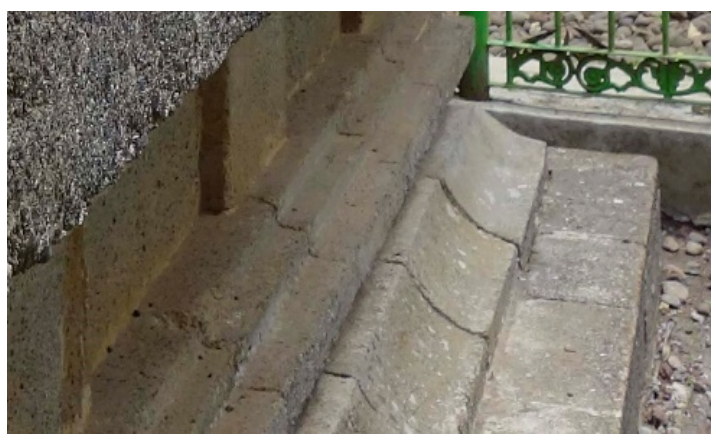

The leg part of Cangkuang Temple does not only have a firm line but also has a curved shape.

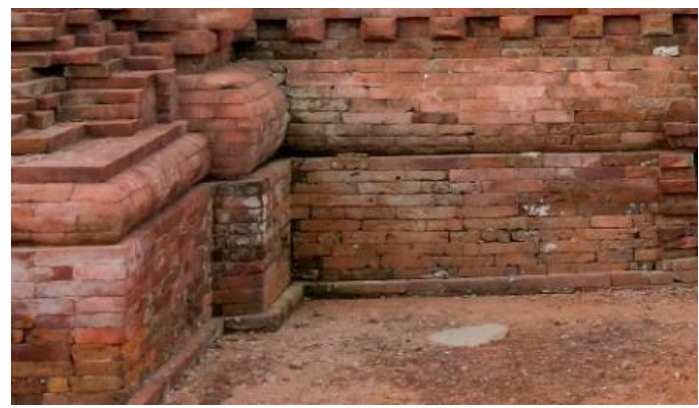

The leg of Batujaya Temple is flat and there are no reliefs.

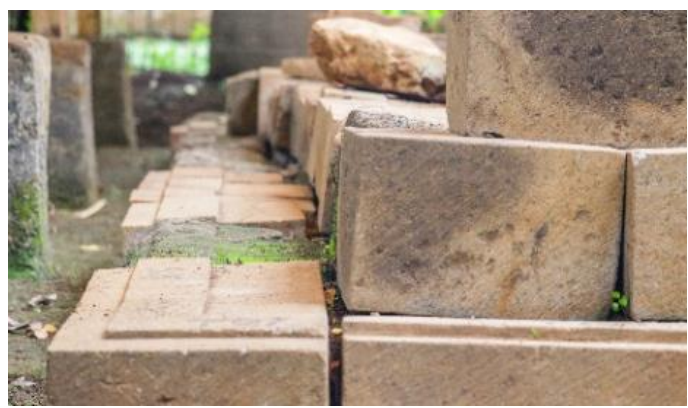

On the leg of Bojong Menje Temple there is a contour with a slight bulge upwards.

Batujaya Temple for the feet uses red brick material so that the visible color is also red. The size of the rock is smaller compared to Bojongmenje Temple and Cangkuang Temple and there are no reliefs. At the foot of Bojongmenje Temple only visible straight lines and the use of andesite rocks. Then at Bojongmenje Temple the foot of the temple uses andesite rocks just like Bojongmenje Temple and 
also do not see any reliefs only rocks with a firm line with the color of gray rocks.

\section{B, The Temple Body}

Here is the body of Batujaya Temple that uses red brick and Cangkuang Temple that uses andesite stone. While in Bojongmenje Temple the author does not see the arrangement of the temple body. There are only temple legs.

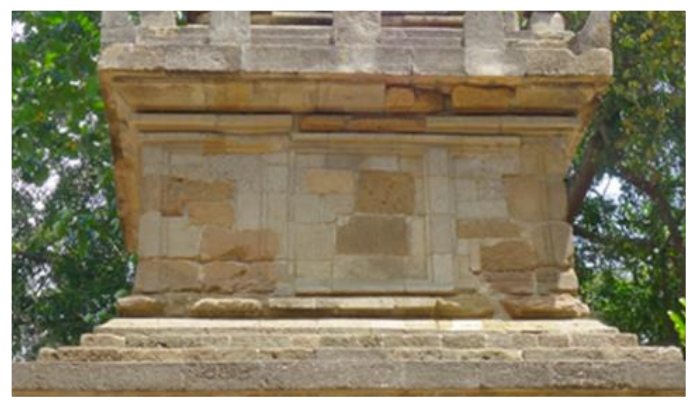

On the body part of Cangkuang Temple there are no reliefs and building materials using andesite rocks.
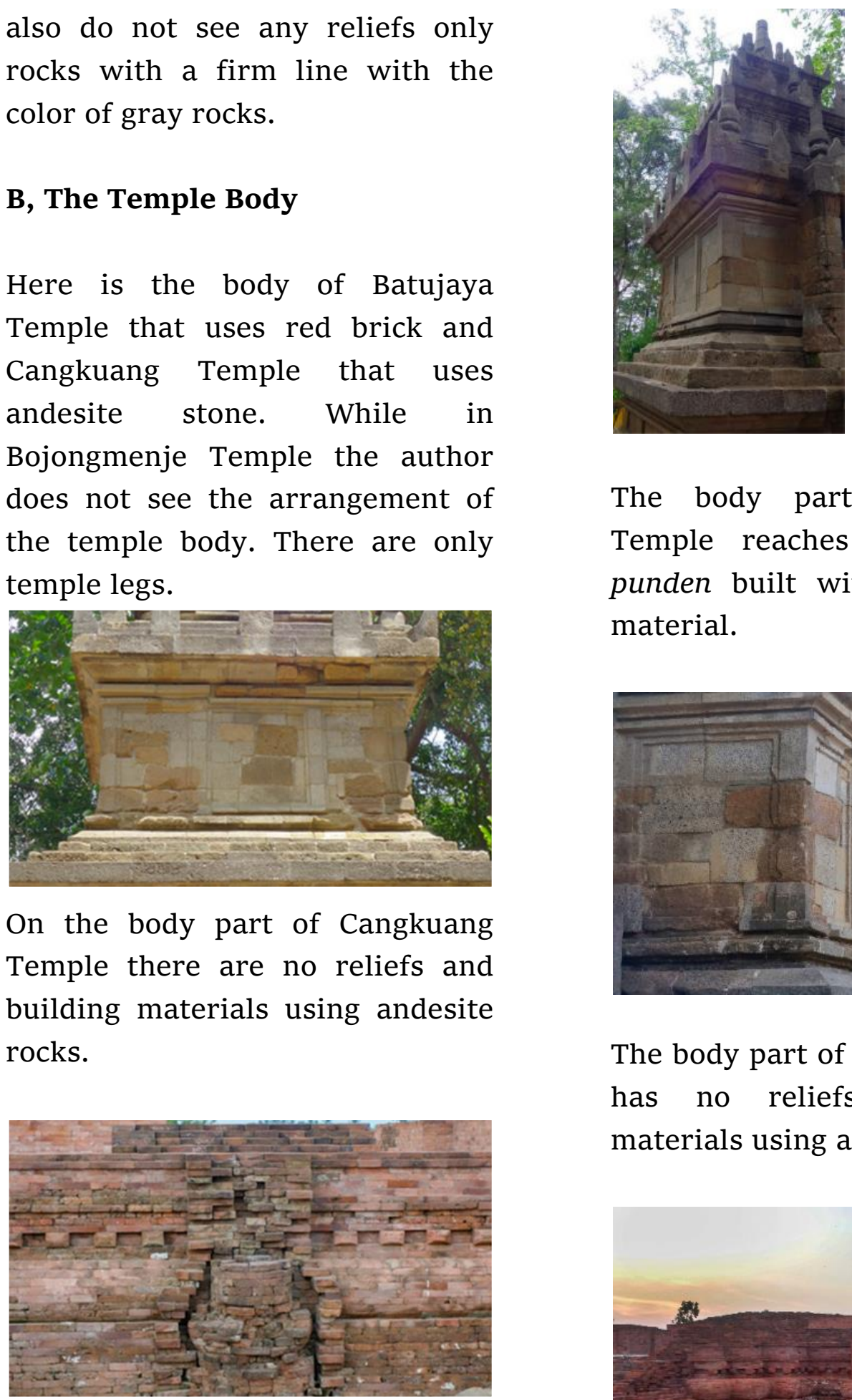

The body part of Cangkuang Temple reaches the roof with punden built with andesite rock material.

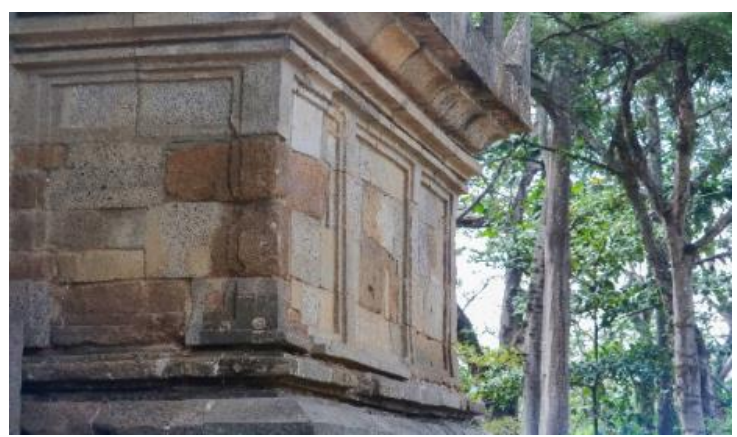

The body part of Candi Cangkuang has no reliefs and building materials using andesite rocks.

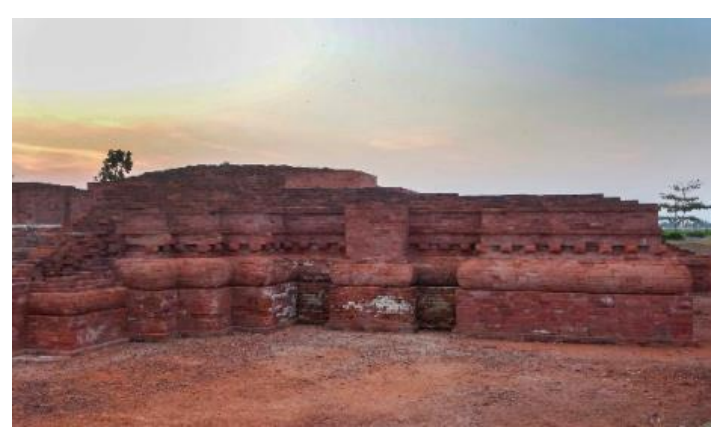

that uses red brick there are no reliefs.

The entire body of Batujaya Temple has no reliefs and building 
materials are used andesite rocks.

The body part in Batujaya Temple does not have the same reliefs as Cangkuang Temple, there is a difference in the type of rock on the body of the temple, in Batujaya Temple in the body using red brick while on the body of Cangkuang Temple using andesite rocks. Both temples have a Hindu temple pattern.

\section{Roof of the Temple}

The following is the roof of Batujaya Temple that has not been arranged and the roof of the cangkuang temple that has been completed. While at Bojongmenje Temple the author did not find the roof of the temple.

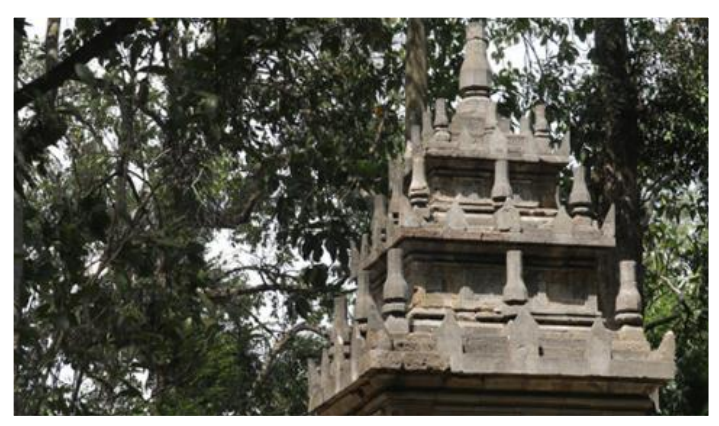

Part of Cangkuang Temple roof with a three-step punden that uses rock material.

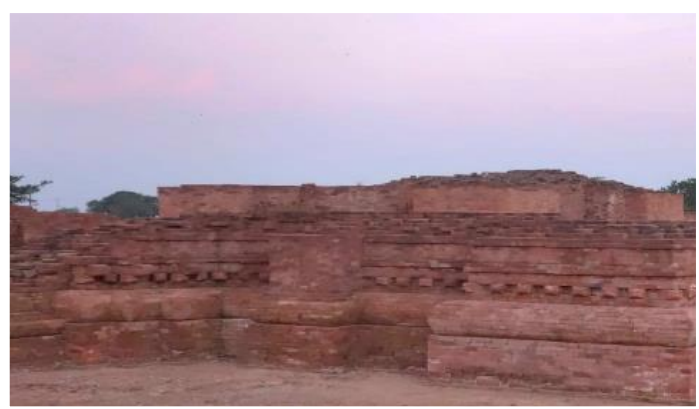

Batujaya Temple has no roof.

Here is a comparison of Candi Cangkuang with Gedong Songo Temple which has a stepped punden and similar ornaments.

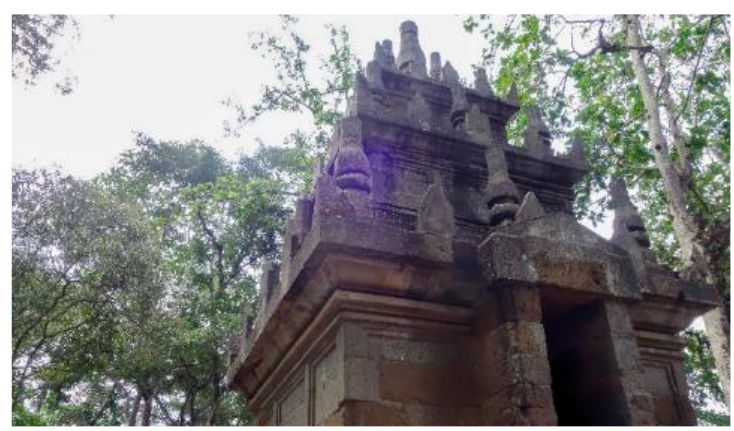

The roof of Cangkuang Temple with a three-step punden that is blackish.

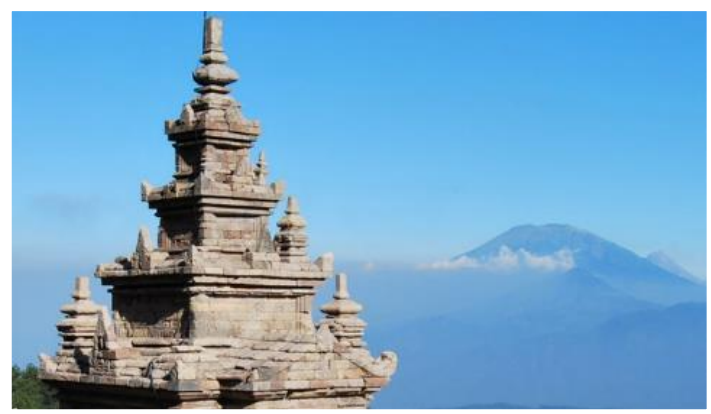

The side part of GedongSongo Temple roof with stepped punden which constructed with andesite 
rocks.

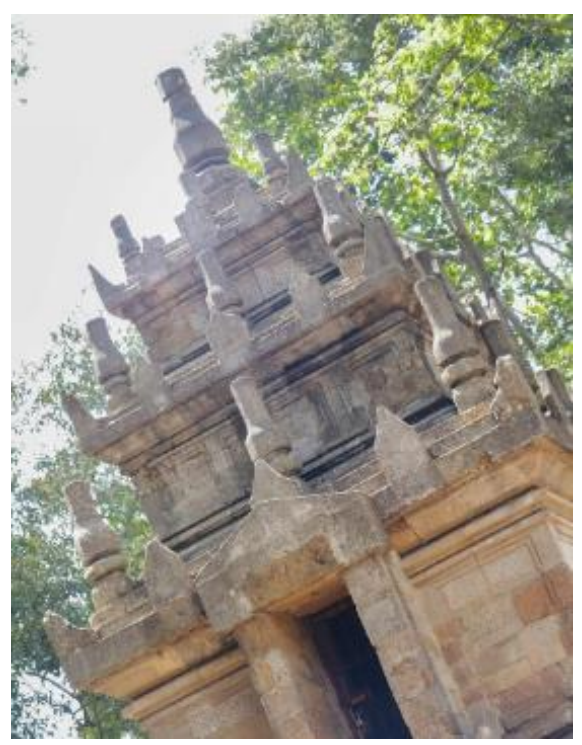

The front side of the roof of Cangkuang Temple with stepped punden constructed with andesite rock material.

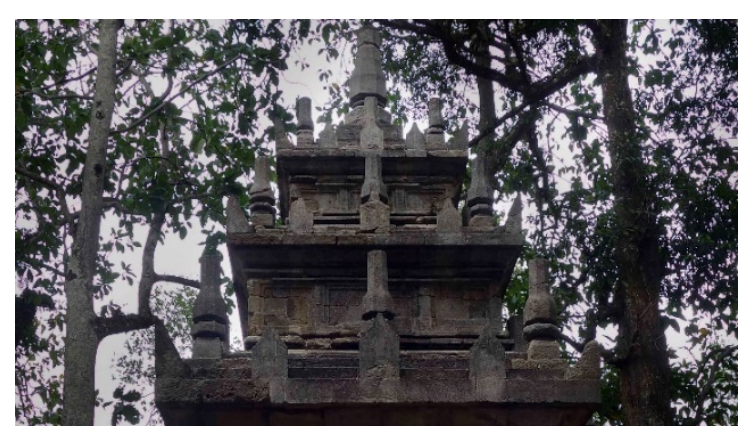

The front side of the roof of Cangkuang Temple with stepped punden constructed with andesite rock material.

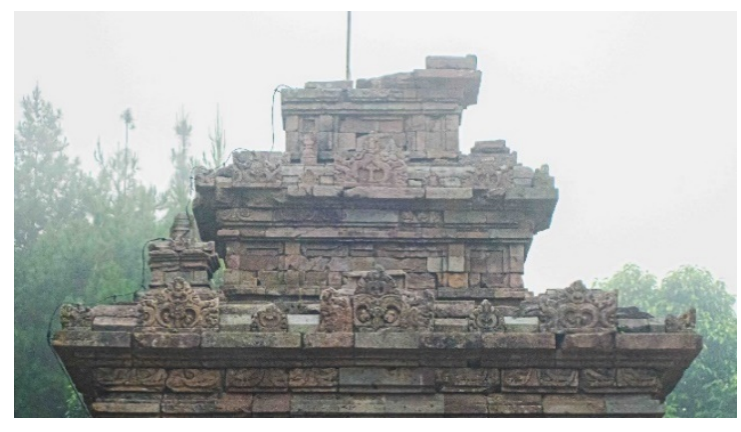

The side part of Gedongsongo Temple roof with stepped punden constructed with andesite rock material.

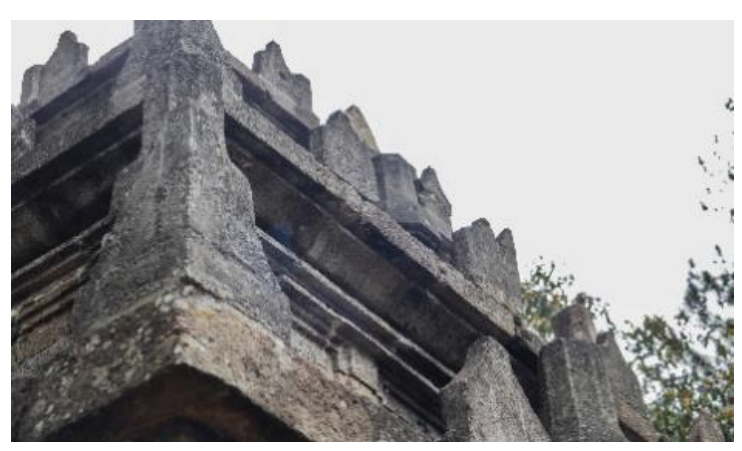

The roof of Cangkuang Temple with a stepped punden is made with andesite rocks.

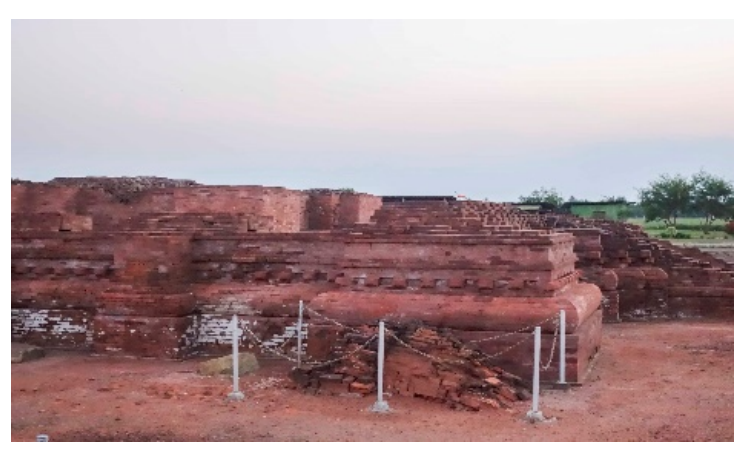

Batujaya Temple does not have a roof. 


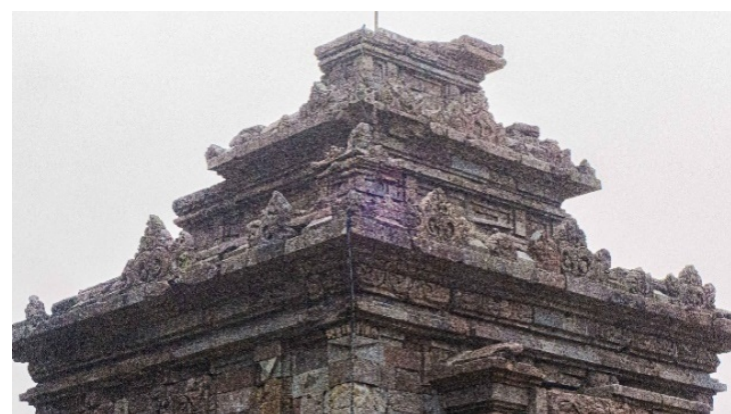

The roof of GedongSongo Temple with a stepped punden is made with andesite rocks.

Among the previous comparison temples, only Cangkuang Temple is restored and in the form of a complete building, ranging from feet, bodies, and roofs with andesite stone materials and stepped punden. While the body part of Batujaya Temple is still with red brick also Bojongmenje Temple is only part of the leg that has built with andesite rock material. For the comparison between Cangkuang and GedongSongo temple is the roof on both temples looks similar to the stepped punden and ornaments that decorate the temple.The similarity of Candi Cangkuang and Gedong Songo Temple is at the time of restoration of Cangkuang Temple only remaining $40 \%$ with the condition of a destroyed roof (Munandar, 2010: 73). And by consensus the time of restoration was considered the same as the temple in Dieng or Gedong Songo.
So that the restoration time is made with the reference of temples in Dieng because in Cangkuang Temple there is a Statue of Shiva that sits on nandi's back that resembles one in the Dieng plateau (Munandar, 2010: 83).

\section{Conclusion}

This conclusion reveals a comparison of temple building characteristics and also a clear description of the differences and characteristics of the temple with the method of visualization of photography with diptych and tryptych juxtaposing technique. The final conclusion is that Cangkuang Temple is indeed most likely a relic of the Ancient Sunda Kingdom. The difference in uniqueness of temple buildings with other Ancient Sundanese heritage buildings is likely due to errors during restoration. The mistake makes there are parts of the temple building whose characteristics actually refer to the era afterwards as shown in the comparison of the roof with Gedong Songo Temple.

\section{References}

A. Acharya, P. K. (1927). Indian Architerctur, According to Manasara -Silpasastra. London: The Oxford Unifersity Press. 
Bull, Stephen. (2010). Photography (Oxon: Routledge)

B. Djafar, H. (2001). Percandian di Situs Batujaya, Karawang: Kajian Arsitektural, Kronologi,danSistemnya.SemilokaPotensidanProspekSi tusPercandianBatujaya Karawang, Jawa barat. Depok: UniversitasIndonesia.

C. Munandar, A. A. (1992). Bangunan Suci pada Masa Kerajaan Sunda: Data Arkeologi dan Sumber Tertulis. dalam Pertemuan Ilmiah Arkeologi VI, Batu, Malang, 26-29.

D. Munandar, A. A. (2004). Menggapai titik suci: Interpretasi Semiotika atas Perpindahan Pusat Kerajaan Mataram Kuna. Semiotika budaya, 161.

E. Munandar, A. A. (2010). Tatar Sunda masa silam. Jakarta: Wedatama Widya Sastra

Munandar, A. A. (2017). Siliwangi, sejarah, dan budaya Sunda Kuno. Jakarta: Wedatama Widya Sastra.

F. Munandar, A. A. (2019). Archaeological artifacts as expressive desire of hindu-buddha religions in java in 8th-15th centuries. International Review of Humanities Studies, 4(2).

G. Munandar, A. A., Fahrudin, D., Sujai, A., \& Rahayu, A. (2011). Bangunan Suci Sunda Kuna. Jakarta: Wedatama Widya Sastra.

First Author Rahmadi, M.Sn. gained Sarjana Seni degree in 20 at Photography Study Program, Universitas Pasundan and master of art in 20 at Fine Art Study Program, Institut Seni Budaya Indonesia; a lecturer at Photography Study Program, Faculty of Art and Letters, Universitas Pasundan; majoring Basic Photography and Visual Anthropology; current research interest in analysing culture in photography or movie and also creating a work of photography fine art. 